\title{
Low-Power Red and Infrared Laser Effects on Cells Deficient in DNA Repair
}

\author{
Lucas Kiyoshi da Fonseca Iwahara', Flavia de Paoli ${ }^{2}$, Adenilson de Souza da Fonseca ${ }^{3,4,5^{*}}$ \\ 'Instituto de Biociências, Universidade Federal do Estado do Rio de Janeiro, Avenida Pasteur, 296, Urca, Rio de Janeiro, \\ 22290240, Brazil \\ ${ }^{2}$ Departamento de Morfologia, Instituto de Ciências Biológicas, Universidade Federal de Juiz de Fora, Rua José Lourenço \\ Kelmer, s/n - Campus Universitário, São Pedro, Juiz de Fora, Minas Gerais, 36036900, Brazil \\ ${ }^{3}$ Laboratório de Biofotônica, Departamento de Biofísica e Biometria, Instituto de Biologia Roberto Alcantara Gomes, \\ Universidade do Estado do Rio de Janeiro, Boulevard Vinte e Oito de Setembro, 87, fundos, $4^{\circ}$ andar, Vila Isabel, Rio de \\ Janeiro, 20551030, Brazil \\ ${ }^{4}$ Departamento de Ciências Fisiológicas, Instituto Biomédico, Universidade Federal do Estado do Rio de Janeiro, Rua Frei \\ Caneca, 94, Rio de Janeiro, 20211040, Brazil \\ ${ }^{5}$ Centro de Ciências da Saúde, Centro Universitário Serra dos Órgãos, Avenida Alberto Torres, 111, Teresópolis, Rio de \\ Janeiro, 25964004, Brazil
}

\section{*Correspondence to \\ Adenilson de Souza da Fonseca, Laboratório de Biofotônica, Departamento de Biofísica e Biometria, Instituto de Biologia Roberto Alcantara Gomes, Universidade do Estado do Rio de Janeiro, Boulevard Vinte e Oito de Setembro, 87, fundos, $4^{\circ}$ andar, Vila Isabel, Rio de Janeiro, 20551030, Brazil. Telephone/Fax: +55 21 23342058,e-mail: adnfonseca@ yahoo.com.br}

Published online July 6, 2019

\begin{abstract}
Introduction: Low-level lasers are successfully used to prevent and treat diseases in soft oral and bone tissues, particularly diseases in oral cavity caused by chemotherapy and radiotherapy in oncology. However, controversy exists as to whether these lasers induce molecular side effects, mainly on DNA. The aim of this work was to assess the effects of low-power lasers on mutant Escherichia coli cells in DNA repair.

Methods: Escherichia coli wild type cultures as well as those lacking recombination DNA repair $\left(r e c A^{-}\right)$and la SOS responses (lex $\left.A^{-}\right)$irradiated with lasers at different energy densities, powers, and emission modes for cell viability and morphology assessment were used in this study.

Results: Laser irradiation: ( $i)$ did not affect cell viability of non-mutant and lexA cells but decreased viability in rec $A$ - cultures; (ii) altered morphology of wild type and lexA, depending on the energy density, power, emission mode, and wavelength.

Conclusion: Results show that low-level lasers have lethal effects on both recombination DNA repair and SOS response bacterial cells but do not induce morphological modifications in these cells.

Keywords: DNA repair; Escherichia coli; Laser therapy.
\end{abstract}

\section{Introduction}

Monochromaticity, directionality, coherency, and light beams with high energy density differentiate lasers from regular radiation sources, making laser devices attractive for clinical applications. The light wavelength and optical properties of the biological tissue determine how deep laser radiation penetrates, and its high energy density and intensity allow high radiation doses to be delivered at high dose ratios. ${ }^{1}$ Also, laser devices work as radiation sources, in continuous or pulsed emission mode, depend on the laser active medium or whether the emission is modulated by an electric current. ${ }^{1}$ For low-level lasers, low energy densities or doses are applied to body tissues according to the therapeutic applications proposed by device guidebooks or laser practitioners. These lasers cause nonthermal and nondestructive effects but alter biological processes increasing the metabolism and cellular division rate, an effect known as biostimulation or biomodulation. In most clinical applications, at a low level, this effect is considered as the photobiological basis for wound healing, ${ }^{2}$ acceleration of tissue repair, nerves, cartilages, bone, soft tissues, as well as the relief from the inflammatory process ${ }^{3}$ and pain. ${ }^{4}$

Absorption of radiation in the optical window of low-level lasers (600 up to $1100 \mathrm{~nm}$ ) occurs by specific chromophores into cells. ${ }^{5}$ Following photon energy absorption, a primary photo signal is generated and amplified in the cells as a consequence of transduction processes. ${ }^{6}$ Free radicals, reactive oxygen, and nitrogen species were suggested as participating in these molecular mechanisms, reacting with biomolecules, and causing cellular function modifications. ${ }^{7}$ However, as $\mathrm{Kim}^{8}$ has suggested, photobiological side effects could occur if an increased free radicals pool is available to react with 
biomolecules, like DNA, causing undesired effects. Side effects induced by low-level lasers are still a matter of controversy, but there are increasing experimental data from sublethal DNA lesions following irradiation of eukaryotic $\mathrm{c}^{7,9,10}$ and prokaryotic cells ${ }^{11,12}$ with these lasers at therapeutic conditions. In other studies, it was demonstrated that previous exposure to low-level lasers induces resistance in $E$. coli cultures sensitive to hydrogen peroxide, ${ }^{13}$ and cell viability is decreased in E. coli cultures after exposure to lasers. ${ }^{12,14}$ In addition, these lasers are capable of inducing a filamentation phenotype, one of SOS responses, induced in some bacterial species exposed to harmful environments. ${ }^{15,16}$

Despite so, low-level laser therapies are used for treatment of diseases, particularly oral cavity diseases induced by chemotherapy and radiotherapy in oncology. The aim of this work was assessing the effects of low power lasers on mutant Escherichia coli cells in DNA repair.

\section{Methods}

Low-Power Lasers

Two therapeutic low-level lasers were used in this study: a red laser (InGaAlP), which emits in $660 \mathrm{~nm}$, and an infrared laser (AsGaAl), which emits in $808 \mathrm{~nm}$ (DMC Equipamentos Ltda, São Paulo, Brazil).

\section{Cell Viability in Escherichia coli Cultures}

In this study, exponentially E. coli AB1157 (not mutant), AB2463 (mutant in RecA protein), and AB2494 (mutant in LexA protein) were used. Following centrifugation (700x g, 15 minutes), washing and suspension in $0.9 \%$ $\mathrm{NaCl}$, samples $(50 \mu \mathrm{L}, \mathrm{n}=5$ for each irradiation condition $)$ of these cells $\left(10^{8}\right.$ cells $\left./ \mathrm{mL}\right)$ were irradiated with lasers $\left(25,50\right.$ and $100 \mathrm{~J} / \mathrm{cm}^{2} ; 30,50$ and $100 \mathrm{~mW}$; continuous, 10 and $100 \mathrm{~Hz}$ ). Laser sources were placed immediately on the bacterial suspensions. Non-irradiated bacterial suspensions were used as controls." Following incubation (18 hours, $37^{\circ} \mathrm{C}$ ), bacterial colonies were counted and survival fractions were calculated as the measurement of cell viability. ${ }^{12}$

\section{Cellular Morphology Assessment}

Bacteria area and perimeter were evaluated following laser irradiation. To do so, bacterial suspensions were irradiated with lasers, under the same conditions as those described in the item above, applied over the microscopic slides and stained by the Gram technique. ${ }^{17}$ Microscopic images of bacteria $(n=300$ for each laser irradiation condition, 40x magnification) were captured by Axion Vision software (Carl Zeiss, Germany) and quantified by Image-Pro Plus software (Media Cybernetics, Inc., USA).

\section{Statistical Analysis}

Bacterial survival fractions, area, and perimeter are presented as means and standard deviation (means \pm SD). One-way analysis of variance was carried out to assess differences between the groups, and Tukey post-test was carried out to compare and explore the differences between the groups. $P<0.05$ was chosen as the significant level. All statistical analyses were conducted by InStat GraphPad software (GraphPad Software Inc., California, USA).

\section{Results}

Cell Viability in Escherichia coli Cultures Irradiated With the Laser

Survival fractions of E. coli AB1157, AB2463, and AB2494 irradiated with low-power lasers are shown in Figures 1, 2 and 3. At $100 \mathrm{~mW}$ and in continuous mode (Figure 1), no alteration in cell viability was obtained when E. coli AB1157 and AB2494 were irradiated with the lasers. However, cell viability was reduced in E. coli AB2463 following irradiation with an infrared laser at the middle energy density $\left(50 \mathrm{~J} / \mathrm{cm}^{2}\right)$. Cell viability was also reduced following irradiation with a red laser at all energy densities. Based on these results, E. coli cultures were exposed to lasers at different powers and $100 \mathrm{~J} / \mathrm{cm}^{2}$ to evaluate whether laser power altered the laser effects.

Data in Figure 2 show that irradiation with both lasers at all powers evaluated did not modify cell viability in E. coli AB1157 and AB2494, but cell viability of E. coli AB2463 cells decreased following red laser irradiation at $100 \mathrm{~mW}$.

Also, bacterial cultures were irradiated with the lasers in the continuous and pulsed modes at higher energy density and power $\left(100 \mathrm{~J} / \mathrm{cm}^{2}, 100 \mathrm{~mW}\right)$. As shown in Figure 3, cell viability was not altered in E. coli AB1157 and AB2494 following exposure to the lasers. However, the lasers altered E. coli AB2463 cell viability, except in the continuous infrared laser.

Morphology of the Bacterial Cells Irradiated With the Lasers

Area and perimeter of E. coli AB1157 cells were measured

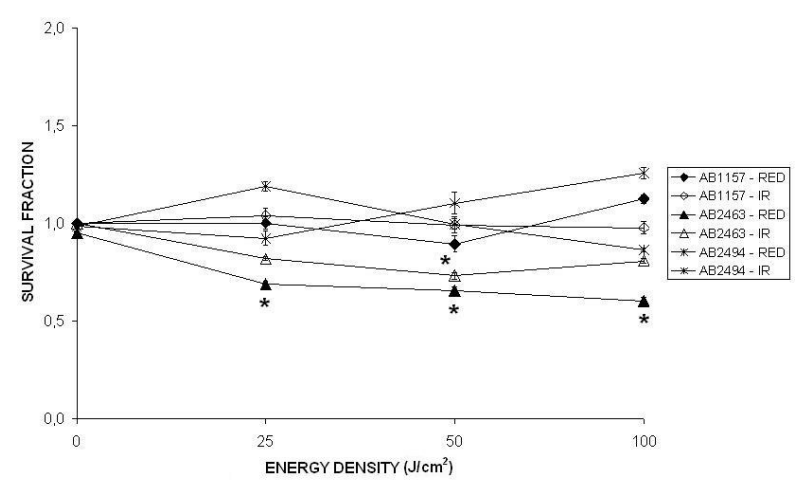

Figure 1. Survival Fractions in Escherichia coli Irradiated With Lasers at Different Energy Densities. Exponentially bacterial cultures $\left(2-5 \times 10^{8}\right.$ cell $\mathrm{s} / \mathrm{mL}$ ) were irradiated with lasers (100 mW, continuous mode). Survival fractions were obtained between the number of irradiated viable cells and the number of non-irradiated viable cells. Data are from 3 experiments. * $P<0.05$ for comparisons between the irradiated and control groups. 


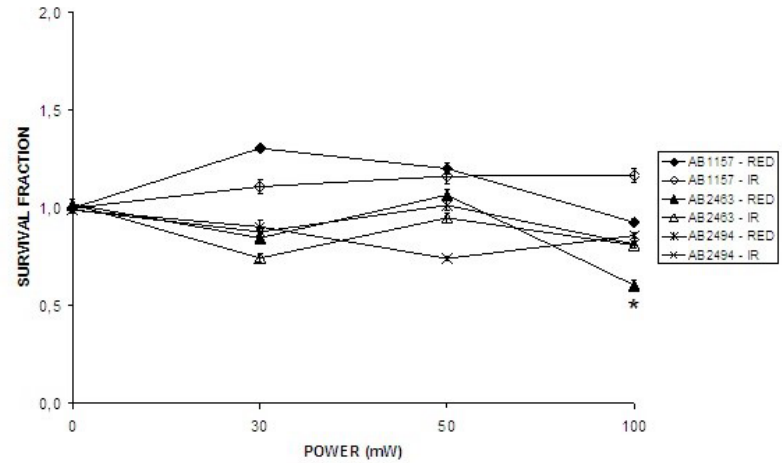

Figure 2. Survival Fractions in Escherichia coli Irradiated With Lasers at Different Powers. Exponentially bacterial cultures $\left(2-5 \times 10^{8} \mathrm{cells} / \mathrm{mL}\right)$ were irradiated with lasers $\left(100 \mathrm{~J} / \mathrm{cm}^{2}\right.$, continuous mode). Survival fractions were obtained between the number of irradiated viable cells and the number of non-irradiated viable cells. Data are from three experiments. ${ }^{*} P<0.05$ for comparisons between the irradiated and control groups.

following irradiation with the lasers (Table 1). While in a continuous mode and at $100 \mathrm{~mW}, 100 \mathrm{~J} / \mathrm{cm}^{2}$ of the red laser, the area of these cells decreased, the infrared laser increased both parameters in these cells. At the lowest powers ( 30 and $50 \mathrm{~mW}$ ), the red laser did not make modifications, but the infrared laser increased the parameters of E. coli AB1157 cells. In a pulsed mode, at $100 \mathrm{~J} / \mathrm{cm}^{2}$ and $100 \mathrm{~mW}$, the red laser was not capable of causing alterations in area and perimeter, while these parameters increased after irradiation with an infrared laser, as it is shown in Table 1.

The area and perimeter values of E. coli AB2463 following irradiation with the lasers are shown in Table 2. The data show an increase in the area of the cells following irradiation with a red laser at the lowest energy densities $\left(25\right.$ and $\left.50 \mathrm{~J} / \mathrm{cm}^{2}\right)$ in the continuous mode at $100 \mathrm{~mW}$, but no perimeter modification. Under the same exposure conditions, the infrared laser did not induce any

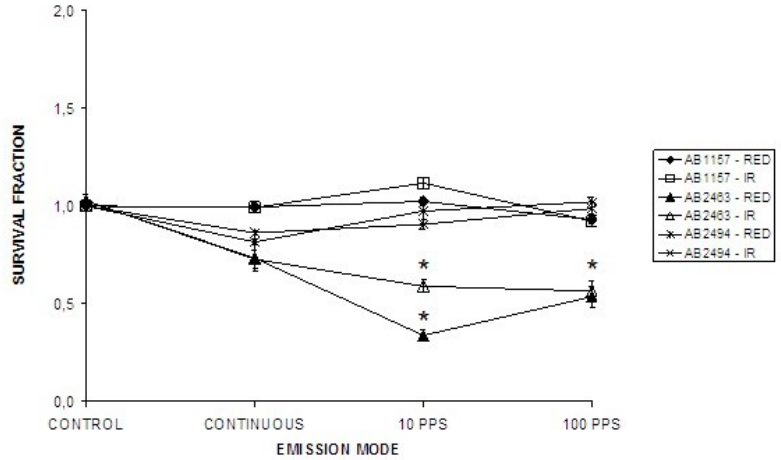

Figure 3. Survival Fractions in Escherichia coli Irradiated With the Lasers in Continuous and Pulsed Modes. Exponentially bacterial cultures (2-5 $x$ 108 cells $/ \mathrm{mL}$ ) were irradiated with the lasers $\left(100 \mathrm{~J} / \mathrm{cm}^{2}, 100 \mathrm{~mW}\right)$. Survival fractions were obtained between the number of irradiated viable cells and the number of non-irradiated viable cells. Data are from 3 experiments. * $P<0.05$ for comparisons between the irradiated and control groups.

modification in these morphological parameters in these cells. Morphological parameters were reduced when $E$. coli AB2463 were irradiated with the red and infrared lasers in the continuous mode at $100 \mathrm{~J} / \mathrm{cm}^{2}$ and $30 \mathrm{~mW}$, but the area of these cells irradiated with the infrared laser was not altered. Also, as shown in Table 2, the lasers did not induce any alteration in area and perimeter in the pulsed emission mode, except for the red laser at $100 \mathrm{~Hz}$.

At $100 \mathrm{~mW}$ in a continuous wave, the lasers did not alter the morphological parameters of E. coli AB2494 in the middle energy density used $\left(50 \mathrm{~J} / \mathrm{cm}^{2}\right)$, but the values of both parameters were reduced at 25 and $100 \mathrm{~J} / \mathrm{cm}^{2}$ (see Table 3). The morphological parameters analyzed were reduced in E. coli AB2494 following irradiation with the lasers at the lowest powers in the continuous mode and at $100 \mathrm{~J} / \mathrm{cm}^{2}$. As shown in Table 3, these parameters were also reduced in the cells irradiated with the lasers at 100 $\mathrm{Hz}$.

Table 1. Morphological Parameters of Escherichia coli AB1157 Following Irradiation With the Lasers

\begin{tabular}{|c|c|c|c|c|}
\hline & \multicolumn{2}{|c|}{ Area $\left(\mu m^{2}\right)$} & \multicolumn{2}{|c|}{ Perimeter $(\mu \mathrm{m})$} \\
\hline & Red & Infrared & Red & Infrared \\
\hline \multicolumn{5}{|c|}{ Energy density $\left(\mathrm{J} / \mathrm{cm}^{2}\right)^{\mathrm{a}}$} \\
\hline Control & $1.9 \pm 0.3$ & $1.9 \pm 0.3$ & $6.0 \pm 1.3$ & $6.0 \pm 1.3$ \\
\hline 25 & $2.0 \pm 0.3$ & $1.6 \pm 0.6$ & $6.4 \pm 0.7$ & $6.1 \pm 1.4$ \\
\hline 50 & $1.8 \pm 0.2$ & $1.8 \pm 0.6$ & $6.3 \pm 0.6$ & $6.5 \pm 1.4$ \\
\hline 100 & $1.6 \pm 0.2^{\mathrm{d}}$ & $2.2 \pm 0.8^{\mathrm{d}}$ & $5.8 \pm 0.8$ & $6.6 \pm 1.4^{\mathrm{d}}$ \\
\hline \multicolumn{5}{|l|}{ Power $(\mathrm{mW})^{\mathrm{b}}$} \\
\hline 30 & $1.8 \pm 0.7$ & $2.3 \pm 0.7^{\mathrm{d}}$ & $6.4 \pm 1.5$ & $6.8 \pm 1.2^{\mathrm{d}}$ \\
\hline 50 & $1.8 \pm 0.6$ & $2.1 \pm 0.6^{\mathrm{d}}$ & $6.3 \pm 1.4$ & $6.5 \pm 1.5^{d}$ \\
\hline 100 & $1.6 \pm 0.2^{\mathrm{d}}$ & $2.2 \pm 0.8^{\mathrm{d}}$ & $5.8 \pm 0.8$ & $6.6 \pm 1.4^{\mathrm{d}}$ \\
\hline \multicolumn{5}{|c|}{ Frequency $(\mathrm{Hz})^{c}$} \\
\hline Continuous & $1.6 \pm 0.2^{*}$ & $2.2 \pm 0.8^{\mathrm{d}}$ & $5.8 \pm 0.8$ & $6.6 \pm 1.4^{\mathrm{d}}$ \\
\hline 10 & $1.7 \pm 0.6$ & $2.0 \pm 0.5^{d}$ & $6.3 \pm 1.4$ & $6.5 \pm 1.7^{\mathrm{d}}$ \\
\hline 100 & $1.7 \pm 0.6$ & $2.2 \pm 0.6^{\mathrm{d}}$ & $6.0 \pm 1.3$ & $6.5 \pm 1.6^{d}$ \\
\hline
\end{tabular}

The continuous wave emission mode at $100 \mathrm{~mW}$.

${ }^{\mathrm{b}}$ The continuous mode at $100 \mathrm{~J} / \mathrm{cm}^{2}$.

c $100 \mathrm{~J} / \mathrm{cm}^{2}$ and $100 \mathrm{~mW}$.

d $P<0.05$ for comparisons between the irradiated and control groups. 
Table 2. Morphological Parameters of Escherichia coli AB2463 Following Irradiation With the Lasers

\begin{tabular}{|c|c|c|c|c|}
\hline & \multicolumn{2}{|c|}{ Area $\left(\mu \mathrm{m}^{2}\right)$} & \multicolumn{2}{|c|}{ Perimeter $(\mu \mathrm{m})$} \\
\hline & Red & Infrared & Red & Infrared \\
\hline \multicolumn{5}{|c|}{ Energy density $\left(\mathrm{J} / \mathrm{cm}^{2}\right)^{\mathrm{a}}$} \\
\hline Control & $2.1 \pm 1.0$ & $2.1 \pm 1.1$ & $6.8 \pm 2.3$ & $6.8 \pm 2.3$ \\
\hline 25 & $2.6 \pm 1.1^{\mathrm{a}}$ & $2.4 \pm 1.3$ & $7.4 \pm 2.4$ & $6.9 \pm 2.9$ \\
\hline 50 & $2.6 \pm 1.1^{\mathrm{a}}$ & $2.0 \pm 0.9$ & $7.2 \pm 2.2$ & $6.4 \pm 2.3$ \\
\hline 100 & $2.1 \pm 0.9$ & $1.9 \pm 0.7$ & $6.6 \pm 2.3$ & $6.4 \pm 1.9$ \\
\hline \multicolumn{5}{|l|}{ Power $(\mathrm{mW})^{b}$} \\
\hline 30 & $1.9 \pm 0.9^{\mathrm{a}}$ & $1.9 \pm 0.9$ & $6.3 \pm 2.2^{\mathrm{a}}$ & $6.2 \pm 2.2^{\mathrm{a}}$ \\
\hline 50 & $2.0 \pm 1.0$ & $2.3 \pm 1.1$ & $6.5 \pm 2.7$ & $6.7 \pm 2.3$ \\
\hline 100 & $2.1 \pm 0.9$ & $1.9 \pm 0.7$ & $6.6 \pm 2.3$ & $6.4 \pm 1.9$ \\
\hline \multicolumn{5}{|c|}{ Frequency $(\mathrm{Hz})^{c}$} \\
\hline Continuous & $2.1 \pm 0.9$ & $1.9 \pm 0.7$ & $6.6 \pm 2.3$ & $6.4 \pm 1.9$ \\
\hline 10 & $2.0 \pm 0.9$ & $2.3 \pm 0.9$ & $6.0 \pm 1.9$ & $6.4 \pm 1.9$ \\
\hline 100 & $1.8 \pm 0.8^{\mathrm{a}}$ & $2.2 \pm 1.0$ & $6.0 \pm 2.1$ & $6.6 \pm 2.1$ \\
\hline
\end{tabular}

a The continuous wave emission mode at $100 \mathrm{~mW}$.

${ }^{\mathrm{b}}$ The continuous mode at $100 \mathrm{~J} / \mathrm{cm}^{2}$.

c $100 \mathrm{~J} / \mathrm{cm}^{2}$ and $100 \mathrm{~mW}$.

d $P<0.05$ for comparisons between the irradiated and control groups.

Table 3. Morphological Parameters of Escherichia coli AB2494 Following Irradiation With the Lasers

\begin{tabular}{|c|c|c|c|c|}
\hline & \multicolumn{2}{|c|}{ Area $\left(\mu \mathrm{m}^{2}\right)$} & \multicolumn{2}{|c|}{ Perimeter $(\mu \mathrm{m})$} \\
\hline & Red & Infrared & Red & Infrared \\
\hline \multicolumn{5}{|c|}{ Energy density $\left(\mathrm{J} / \mathrm{cm}^{2}\right)^{\mathrm{a}}$} \\
\hline Control & $1.8 \pm 0.6$ & $1.8 \pm 0.6$ & $5.8 \pm 1.3$ & $5.8 \pm 1.3$ \\
\hline 25 & $1.6 \pm 0.5^{\mathrm{d}}$ & $1.4 \pm 0.5^{\mathrm{d}}$ & $5.4 \pm 1.3^{\mathrm{d}}$ & $5.2 \pm 1.5^{d}$ \\
\hline 50 & $1.9 \pm 0.6$ & $1.7 \pm 0.6$ & $5.8 \pm 1.3$ & $5.5 \pm 1.2$ \\
\hline 100 & $1.1 \pm 0.3^{\mathrm{d}}$ & $1.6 \pm 0.5^{\mathrm{d}}$ & $5.5 \pm 1.2^{\mathrm{d}}$ & $5.3 \pm 1.2^{\mathrm{d}}$ \\
\hline \multicolumn{5}{|l|}{ Power $(\mathrm{mW})^{\mathrm{b}}$} \\
\hline 30 & $1.1 \pm 0.3^{\mathrm{d}}$ & $1.2 \pm 0.3^{\mathrm{d}}$ & $4.4 \pm 0.8^{\mathrm{d}}$ & $4.6 \pm 0.8^{d}$ \\
\hline 50 & $1.2 \pm 0.4^{\mathrm{d}}$ & $1.1 \pm 0.3^{\mathrm{d}}$ & $4.6 \pm 0.9^{d}$ & $4.4 \pm 0.8^{\mathrm{d}}$ \\
\hline 100 & $1.1 \pm 0.3^{\mathrm{d}}$ & $1.6 \pm 0.5^{\mathrm{d}}$ & $5.5 \pm 1.2^{\mathrm{d}}$ & $5.3 \pm 1.2^{\mathrm{d}}$ \\
\hline \multicolumn{5}{|c|}{ Frequency $(\mathrm{Hz})^{\mathrm{c}}$} \\
\hline Continuous & $1.1 \pm 0.3^{\mathrm{d}}$ & $1.6 \pm 0.5^{\mathrm{d}}$ & $5.5 \pm 1.2^{\mathrm{d}}$ & $5.3 \pm 1.2^{\mathrm{d}}$ \\
\hline 10 & $1.7 \pm 0.5$ & $1.5 \pm 0.6$ & $5.7 \pm 1.3$ & $5.4 \pm 1.6$ \\
\hline 100 & $1.4 \pm 0.4^{\mathrm{d}}$ & $1.2 \pm 0.4^{\mathrm{d}}$ & $5.3 \pm 1.2^{\mathrm{d}}$ & $4.8 \pm 1.2^{\mathrm{d}}$ \\
\hline
\end{tabular}

a The continuous wave emission mode at $100 \mathrm{~mW}$.

${ }^{\mathrm{b}}$ The continuous mode at $100 \mathrm{~J} / \mathrm{cm}^{2}$.

c $100 \mathrm{~J} / \mathrm{cm}^{2}$ and $100 \mathrm{~mW}$.

d $P<0.05$ for comparisons between the irradiated and control groups.

\section{Discussion}

Cells have different DNA repair mechanisms to maintain chromosomal stability and resist various aggressive agents in the environment. E. coli strains presenting deficiency in a specific DNA repair mechanism allow for evaluating the participation of this specific mechanism as part of the survival strategy or adaptation to changes in environmental conditions or exposure to harmful agents.

Cell viability in $E$. coli AB1157 cultures, not mutant for DNA repair mechanisms, is not altered following irradiation with the lasers at energy densities, powers, and frequencies for therapeutical protocols (Figures 1, 2 and 3). These results could suggest that the therapeutic lasers have no lethal effect on or risk to chromosomal stability in cells presenting all DNA repair mechanisms. However, there are error-prone DNA repair mechanisms which repair DNA lesions but can compromise the genetic code and DNA stability causing mutations. In bacterial cells, these mechanisms are represented by inducible mechanisms participating in SOS responses, which include filamentation phenotype, prophage lytic cycle induction and mutagenic DNA repair. Thus, an agent capable of inducing SOS responses could be able to induce mutations in DNA. E. coli AB2463 cells present deficiency in recA protein, a recombinase, and this does not present an inducible SOS response, neither does this present recombination and postreplication repair mechanism. ${ }^{18}$ Cell viability in E. coli AB2463 culture 
was reduced following irradiation with an infrared laser, mainly after irradiation with a red laser at $100 \mathrm{~mW}$ in the continuous and pulsed modes (Figures 1, 2 and 3). This suggests that SOS responses and recombination repair are mechanisms used in cell survival or adaptation to the effects of the infrared and red monochromatic radiation at low intensities. However, which gene involved in the control of SOS responses is important for cell survival or adaptation to these radiations? For this, cell viability in E. coli AB2494 cultures was evaluated because these cells, like E. coli AB2463, are deficient in SOS responses and proficient in recombination DNA repair, but they present a mutation in lexA gene, which codes SOS response repressor. ${ }^{19}$ Interestingly, our results showed that the lasers did not affect cell viability in cultures of these cells (Figures 1,2 and 3). This demonstrates that the global molecular mechanism of the survival or adaptation of cells to the low-level lasers is lexA-independent but dependent on recombination repair.

Induction of filamentation phenotype is reported in $E$. coli cells irradiated with the low-level lasers, as in those with mutations in genes related to DNA repair pathways for oxidative damages. ${ }^{15,16,20}$ However, the filamentation assay performed in these studies did not allow for evaluating what happened with cells which do not present this phenotype. To attempt this need, area and perimeter were measured in mutant E. coli cells in SOS functions (AB2463 and AB2494) and compared to E. coli wild type cells (AB1157). Table 1 shows that the infrared laser, compared to the red laser, seems to have more effect on wild type cells, increasing both area and perimeter. Area and perimeter of wild type cells are reduced by the red laser and increased by the infrared laser radiation depending on the energy density, power, and emission mode. These findings confirm that the laser effects depend on physical laser parameters. ${ }^{12}$ In comparison with wild type cells, morphological parameters analyzed in E. coli AB2463 cells were less modified by laser radiation (Table 2 ). The red laser increased area at the lowest energy densities and powers in the pulsed emission mode while the infrared laser caused a slight perimeter reduction. Similar to wild type cells, the lasers induced striking changes in the morphology of E. coli AB2494 cells (Table 3). Results from these two mutant $E$. coli cells confirm that the laser effects depend on the repair of damages to the DNA molecule. ${ }^{12}$

On the other hand, a low-level red laser modifies slow potassium currents, ${ }^{21}$ and the ion flux through $\mathrm{K}^{+}$and $\mathrm{Ca}^{2+}$ channels is high following irradiation with a red laser. ${ }^{22}$ Moreover, an infrared laser increases transmembrane potential in mitochondria and decreases $\mathrm{Ca}^{+2}$ levels into cells. ${ }^{23}$ Alterations of area and perimeter could be related to modifications in the membrane ion channels of the $E$. coli cells.

However, these laser-induced effects on cellular morphology could be dependent on RecA protein but not on LexA protein albeit experiments are necessary to evaluate the relations between the ionic currents through cellular membrane and SOS response.

\section{Conclusion}

This study suggests that the low-power red and infrared lasers have a lethal effect on mutant cells in both recombination DNA repair and SOS response but do not induce morphological modifications in these cells. Our results reinforce the point that DNA repair mechanisms participate in the effects of the low-power lasers, which should be taken into account when laser therapy is performed.

\section{Ethical Considerations \\ Not applicable.}

\section{Conflict of Interests}

The authors declare no conflict of interest.

\section{Acknowledgements}

The Fundação de Amparo à Pesquisa do Estado do Rio de Janeiro (FAPERJ) sponsored this research.

\section{References}

1. Niemz MH. Laser-tissue interactions: Fundamentals and applications. New York: Springer-Verlag; 2007.

2. Peplow PV, Chung TY, Baxter GD. Laser photobiomodulation of wound healing: a review of experimental studies in mouse and rat animal models. Photomed Laser Surg. 2010;28(3):291-325. doi:10.1089/ pho.2008.2446

3. de Moraes Maia ML, Bonjardim LR, de Souza Siqueira Quintans J, Ribeiro MA, Maia LG, Conti PC. Effect of low-level laser therapy on pain levels in patients with temporomandibular disorders: a systematic review. J Appl Oral Sci. 2012;20(6):594-602.

4. Gross AR, Dziengo S, Boers O, et al. Low Level Laser Therapy (LLLT) for Neck Pain: A Systematic Review and Meta-Regression. Open Orthop J. 2013;7:396-419. doi:10.2174/1874325001307010396

5. Karu T. Primary and secondary mechanisms of action of visible to near-IR radiation on cells. J Photochem Photobiol B. 1999;49(1):1-17. doi:10.1016/s1011-1344(98)00219-x

6. Karu T, Pyatibrat L. Gene expression under laser and lightemitting diodes radiation for modulation of cell adhesion: Possible applications for biotechnology. IUBMB Life. 2011;63(9):747-753. doi:10.1002/iub.514

7. Hawkins DH, Abrahamse $\mathrm{H}$. The role of laser fluence in cell viability, proliferation, and membrane integrity of wounded human skin fibroblasts following helium-neon laser irradiation. Lasers Surg Med. 2006;38(1):74-83. doi:10.1002/lsm.20271

8. Kim YG. Laser mediated production of reactive oxygen and nitrogen species; implications for therapy. Free Radic Res. 2002;36(12):1243-1250.

9. Godon C, Cordelieres FP, Biard D, et al. PARP inhibition versus PARP-1 silencing: different outcomes in terms of single-strand break repair and radiation susceptibility. Nucleic Acids Res. 2008;36(13):4454-4464. doi:10.1093/nar/ 
gkn403

10. Mbene AB, Houreld NN, Abrahamse H. DNA damage after phototherapy in wounded fibroblast cells irradiated with $16 \mathrm{~J} / \mathrm{cm} 2$. J Photochem Photobiol B. 2009;94(2):131137. doi:10.1016/j.jphotobiol.2008.11.002

11. Kohli R, Gupta PK. Irradiance dependence of the He-Ne laser-induced protection against UVC radiation in E. coli strains. J Photochem Photobiol B. 2003;69(3):161-167.

12. Fonseca AS, Geller M, Bernardo Filho M, Valenca SS, de Paoli F. Low-level infrared laser effect on plasmid DNA. Lasers Med Sci. 2012;27(1):121-130. doi:10.1007/s10103011-0905-2

13. Fonseca AS, Moreira TO, Paixao DL, et al. Effect of laser therapy on DNA damage. Lasers Surg Med. 2010;42(6):481488. doi:10.1002/lsm.20921

14. Teixeira GR, Sergio LPS, Marciano RS,Polignano GAC, Guimarães OR, Geller M,Paoli F, Fonseca AS. Infrared laser effects at fluences used for treatment of dentin hypersensitivity on DNA repair in Escherichia coli and plasmids. Opt Laser Technol. 2014;64:46-52. doi:10.1016/j. optlastec.2014.04.023

15. Fonseca AS, Presta GA, Geller M, Paoli F. Low intensity infrared laser induces filamentation in Escherichia coli cells. Laser Phys. 2011;21(10):1829-1837. doi:10.1134/ s1054660x11170051

16. da Silva Marciano R, da Silva Sergio LP, Polignano GA, et al. Laser for treatment of aphthous ulcers on bacteria cultures and DNA. Photochem Photobiol Sci. 2012;11(9):1476-1483.
doi:10.1039/C2PP25027F

17. Cappuccino JG, Sherman N. Microbiology: a laboratory manual. California: Benjamin Cummings Science Publishing; 1999.

18. Kacinski BM, Rupp WD, Ludlum DB. Repair of haloethylnitrosourea-induced DNA damage in mutant and adapted bacteria. Cancer Res. 1985;45(12 Pt 1):6471-6474.

19. Koch WH, Woodgate R. The SOS response. In: Nickoloff JA, Hoekstra MF, eds. DNA Damage and Repair. Volume I: DNA Repair in Procaryotes and Lower Eukaryotes. New Jersey: Humana Press; 1998:107-134.

20. Canuto KS, Sergio LPS, Marciano RS, et al. DNA repair in bacterial cultures and plasmid DNA exposed to infrared laser for treatment of pain. Laser Phys Lett. 2013;10(6):065606. doi:10.1088/1612-2011/10/6/065606

21. Ignatov YD, Vislobokov AI, Vlasov TD, Kolpakova ME, Mel'nikov KN, Petrishchev IN. Effects of helium-neon laser irradiation and local anesthetics on potassium channels in pond snail neurons. Neurosci Behav Physiol. 2005;35(8):871-875. doi:10.1007/s11055-005-0137-7

22. Giannelli M, Chellini F, Sassoli C, et al. Photoactivation of bone marrow mesenchymal stromal cells with diode laser: effects and mechanisms of action. J Cell Physiol. 2013;228(1):172-181. doi:10.1002/jcp.24119

23. Huang YY, Nagata K, Tedford CE, Hamblin MR. Low-level laser therapy $(810 \mathrm{~nm})$ protects primary cortical neurons against excitotoxicity in vitro. J Biophotonics. 2014;7(8):656664. doi:10.1002/jbio.201300125 